\title{
Pilidiostigmin, a novel bioactive dimeric acylphloroglucinol derivative isolated from Pilidiostigma glabrum
}

\author{
Qingyao Shou $^{\mathrm{a}, *}$, Han Sun ${ }^{\mathrm{b}}$, Linda K. Banbury ${ }^{\mathrm{a}}$, Eleanore H. Lambley ${ }^{\mathrm{a}}$, Dane E. Renshaw ${ }^{\mathrm{a}}$, \\ Christian Griesinger ${ }^{\mathrm{b}}$, Hans J. Griesser ${ }^{\mathrm{c}}$, Hans Wohlmuth ${ }^{\mathrm{a}}$ \\ a Southern Cross Plant Science, Southern Cross University, PO Box 157, Lismore, NSW 2480, Australia \\ ${ }^{\mathrm{b}}$ Department of NMR Based Structural Biology, Max Planck Institute for Biophysical Chemistry, Am Fassberg 11, 37077 Göttingen, Germany \\ ${ }^{\mathrm{c}}$ Ian Wark Research Institute, University of South Australia, Mawson Lakes, SA 5095, Australia
}

\section{A R T I C L E I N F O}

\section{Article history:}

Received 12 November 2012

Revised 11 January 2013

Accepted 24 January 2013

Available online 4 February 2013

\section{Keywords:}

Pilidiostigma glabrum

Acylphloroglucinol derivative

Pilidiostigmin

Inhibition of NO synthesis

\begin{abstract}
A B S T R A C T
Pilidiostigmin, a novel dimeric acylphloroglucinol derivative, was isolated from the leaves of the Australian plant species Pilidiostigma glabrum (Myrtaceae). Pilidiostigmin exists in the plant in the form of a sodium salt, which is rare in natural products. The elucidation of the structure and relative configuration was achieved by spectroscopic measurements with special emphasis on 1D and 2D NMR techniques. Pilidiostigmin was found to display biological activity; it significantly and dose-dependently inhibited the synthesis of nitric oxide in LPS-stimulated RAW 264.7 macrophages at low micromolar concentrations.
\end{abstract}

(c) 2013 Elsevier Ltd. All rights reserved.
Pilidiostigma glabrum Burret (Myrtaceae), an endemic Australian plant commonly known as plum myrtle, is distributed in southeastern Queensland and north-eastern New South Wales. ${ }^{1}$ In the course of our screening work of native Australian plants with anti-inflammatory activity, the $\mathrm{CHCl}_{3}$ soluble part of the $95 \% \mathrm{EtOH}$ extract of the leaves of $P$. glabrum was found to attenuate significantly nitric oxide (NO) production in vitro. Six dibenzofurans were subsequently isolated from the $\mathrm{CHCl}_{3}$ fraction in our previous investigation. ${ }^{2}$ In a systematic approach to identify the active compounds, we proceeded to further investigate the chemical constituents of the $\mathrm{CHCl}_{3}$ fraction. Herein, we report the isolation and structure elucidation of a novel acylphloroglucinol derivative named pilidiostigmin and the inhibitory effect of this compound on the synthesis of nitric oxide in LPS-stimulated RAW 264.7 macrophages.

The chloroform fraction of the ethanol leaf extract was purified by repeated column chromatography over MCI gel (CHP20P) eluting with methanol/water (80-100\%), C18 (Separa C18-E, $50 \mu \mathrm{m}$, Phenomenex) eluting with methanol/water (80-90\%), and preparative HPLC using an acetonitrile-water gradient to afford pilidiostigmin (8 mg) (Fig. 1).

Pilidiostigmin, obtained as a yellow oil, showed an $[\mathrm{M}+1]^{+}$peak at 855.2622 (calcd 855.2840) and an $[\mathrm{M}-1]^{-}$peak at 853.2707 (calcd 853.2684) according to high-resolution electrospray-

\footnotetext{
* Corresponding author. Tel.: +612 66203572; fax: +61266223459.

E-mail address: qingyao.shou@scu.edu.au (Q. Shou).
}

ionization time of flight mass spectroscopy (HR-ESI-TOF-MS), corresponding to the molecular formula $\mathrm{C}_{44} \mathrm{H}_{48} \mathrm{O}_{16} \mathrm{Na}$. Eight methyl groups with chemical shifts in the range of $\delta_{\mathrm{H}} 1.24-1.35$ were observed in the ${ }^{1} \mathrm{H}$ NMR spectrum, showing correlations with four methine multiplets at $\delta_{\mathrm{H}} 3.92,4.09,4.12$, and 4.28 in the ${ }^{1} \mathrm{H}-{ }^{1} \mathrm{H}$ COSY, which indicated the presence of four 2-methylpropionyl moieties. Four tertiary methyls were also observed at $\delta_{\mathrm{H}} 2.31$, $2.29,1.88$, and 1.73 , and two of them were evidently aromatic methyls. Six downfield protons at $\delta_{\mathrm{H}} 10.58,11.78,13.83,13.88$, 17.10 , and 18.59 assignable to six hydrogen bonds of the $\mathrm{OH}$ groups chelated to carbonyl or $\mathrm{OH}$ groups were also observed.

In addition, the ${ }^{13} \mathrm{C}$ JMOD as well as the HSQC experiments showed eight methyl groups with chemical shifts in the range of $\delta_{\mathrm{C}} 19.0-20.0\left(\delta_{\mathrm{C}} 19.0,19.2,19.4,19.5,19.5,19.5,19.9\right.$, and 20.0$)$, two aromatic methyls at $\delta_{\mathrm{C}} 8.0$ and 8.1, two tertiary methyls at $\delta_{\mathrm{C}} 27.4$ and 28.8 , two oxygenated quaternary carbons at $\delta_{\mathrm{C}} 70.3$ and 73.4, and six ketone carbons at $\delta_{\mathrm{C}} 212.6,212.5,208.9,204.7$, 202.0 , and 196.6. The remaining carbon signals were quaternary carbons of the benzene rings and double bonds. These data, together with additional analysis of the 2D NMR spectra, revealed the presence of two units of similar magnetic resonance signals, which indicated the dimeric nature of the compound.

In one fragment, the two hydroxyl protons at $\delta_{\mathrm{H}} 10.58$ and 13.88 were located on both sides of a 2-methylpropionyl moiety in a benzene ring, based on the formation of hydrogen bonds as well as the HMBC correlations (Fig. 2). In the HMBC spectrum, the correlations of the hydroxyl proton at $\delta_{\mathrm{H}} 10.58$ with $\delta_{\mathrm{c}} 102.0$ 


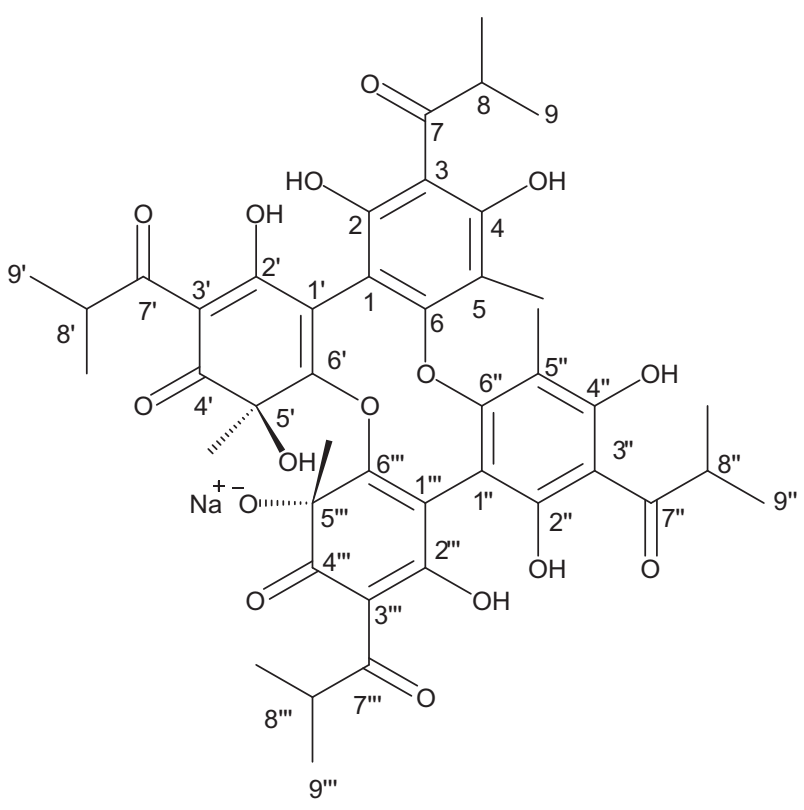

Figure 1. Structure of pilidiostigmin with $5^{\prime} R$ and $5^{\prime \prime \prime} R$ configuration.

$(\mathrm{C}-1), \delta_{\mathrm{c}} 152.3(\mathrm{C}-2)$, and $\delta_{\mathrm{c}} 106.6$ (C-3) suggested assignment of this hydroxyl group at position 2. The HMBC spectrum also displayed correlations of the hydroxyl proton at $\delta_{\mathrm{H}} 13.88$ with the carbon resonances at $\delta_{\mathrm{C}} 106.6(\mathrm{C}-3), \delta_{\mathrm{C}} 162.9(\mathrm{C}-4)$, and $\delta_{\mathrm{C}} 101.1(\mathrm{C}-5)$, as well as of the methyl protons at $\delta_{\mathrm{H}} 2.29$ with the carbon resonances at $\delta_{\mathrm{C}} 162.9(\mathrm{C}-4), \delta_{\mathrm{C}} 101.1(\mathrm{C}-5)$, and $\delta_{\mathrm{C}} 159.1(\mathrm{C}-6)$. This enabled unequivocal assignment of the position of this hydroxyl group at C-4 and the aromatic methyl at position 5 . One characteristic enol proton was also observed at $\delta_{\mathrm{H}} 17.10$; this was chelated to the carbonyl of a 2-methylpropionyl moiety, indicating the presence of a cyclohexadienone ring. ${ }^{3}$ The presence of carbon signals due to one carbonyl group at $\delta_{\mathrm{C}} 196.6$ and two double bonds at $\delta_{\mathrm{C}} 187.8, \delta_{\mathrm{C}} 105.8, \delta_{\mathrm{C}} 117.2$, and $\delta_{\mathrm{C}} 164.4$ supported a cyclohexadienone ring rather than a benzene ring. ${ }^{4}$ The HMBC correlations of the enol proton with the carbon resonance at $\delta_{\mathrm{C}} 105.8\left(\mathrm{C}-3^{\prime}\right), \delta_{\mathrm{C}}$ $204.7\left(\mathrm{C}-7^{\prime}\right)$, and $\delta_{\mathrm{C}} 33.9\left(\mathrm{C}-8^{\prime}\right)$ indicated the presence of a 2-methylpropionyl moiety at position $3^{\prime}$. The HMBC correlations of the methyl protons at $\delta_{\mathrm{H}} 1.73$ with the carbon resonances at $\delta_{\mathrm{C}} 196.6$ $\left(\mathrm{C}-4^{\prime}\right), \delta_{\mathrm{C}} 73.4\left(\mathrm{C}-5^{\prime}\right)$, and $\delta_{\mathrm{C}} 164.4\left(\mathrm{C}-6^{\prime}\right)$ located the tertiary methyl at position $5^{\prime}$. However, due to the absence of HMBC correlations between the benzene ring and the cyclohexadienone ring, these two moieties could either be directly connected via a single bond or linked via an ether bond. In order to identify the correct constitution, a comparison between the optimized structural models
Table 1

${ }^{1} \mathrm{H}$ and ${ }^{13} \mathrm{C}$ NMR data of pilidiostigmin ( $\delta$ values in $\left.\mathrm{ppm}\right)^{\mathrm{a}}$

\begin{tabular}{|c|c|c|}
\hline Position & $\delta_{\mathrm{H}}$ & $\delta_{\mathrm{C}}$ \\
\hline 1 & - & 102.0 \\
\hline 2 & - & 152.3 \\
\hline 3 & - & 106.6 \\
\hline 4 & - & 162.9 \\
\hline 5 & - & 101.1 \\
\hline 6 & - & 159.1 \\
\hline 7 & - & 212.5 or 212.6 \\
\hline 8 & $4.09,1 \mathrm{H}, \mathrm{m}$ & 40.1 \\
\hline $1^{\prime}$ & - & 117.2 \\
\hline $2^{\prime}$ & - & 187.8 \\
\hline $3^{\prime}$ & - & 105.8 \\
\hline $4^{\prime}$ & - & 196.6 \\
\hline $5^{\prime}$ & - & 73.4 \\
\hline $6^{\prime}$ & - & 164.4 \\
\hline $7^{\prime}$ & - & 204.7 \\
\hline $8^{\prime}$ & $3.92,1 \mathrm{H}, \mathrm{m}$ & 33.9 \\
\hline $1^{\prime \prime}$ & - & 103.8 \\
\hline $2^{\prime \prime}$ & - & 153.4 \\
\hline $3^{\prime \prime}$ & - & 106.5 \\
\hline $4^{\prime \prime}$ & - & 163.0 \\
\hline $5^{\prime \prime}$ & - & 101.7 \\
\hline $6^{\prime \prime}$ & - & 159.3 \\
\hline $7^{\prime \prime}$ & - & 212.6 or 212.5 \\
\hline $8^{\prime \prime}$ & $4.12,1 \mathrm{H}, \mathrm{m}$ & 40.2 \\
\hline $1^{\prime \prime \prime}$ & - & 114.3 \\
\hline $2^{\prime \prime \prime}$ & - & 182.5 \\
\hline $3^{\prime \prime \prime}$ & - & 106.5 \\
\hline $4^{\prime \prime \prime}$ & - & 202.0 \\
\hline $5^{\prime \prime \prime}$ & - & 70.3 \\
\hline $6^{\prime \prime \prime}$ & - & 159.8 \\
\hline $7^{\prime \prime \prime}$ & - & 208.9 \\
\hline $8^{\prime \prime \prime}$ & $4.28,1 \mathrm{H}, \mathrm{m}$ & 35.6 \\
\hline 5-Me & 2.29 & 8.0 \\
\hline $5^{\prime}-\mathrm{Me}$ & $1.73, \mathrm{~s}$ & 28.8 \\
\hline $5^{\prime \prime}-\mathrm{Me}$ & 2.31 & 8.1 \\
\hline $5^{\prime \prime \prime}-\mathrm{Me}$ & $1.88, \mathrm{~s}$ & 27.4 \\
\hline $2-\mathrm{OH}$ & $10.58, \mathrm{~s}$ & - \\
\hline $2^{\prime}-\mathrm{OH}$ & $17.10, \mathrm{~s}$ & - \\
\hline $4-\mathrm{OH}$ & $13.88, \mathrm{~s}$ & - \\
\hline $4^{\prime \prime}-\mathrm{OH}$ & 13.83, s & - \\
\hline $2^{\prime \prime}-\mathrm{OH}$ & $11.78, \mathrm{~s}$ & - \\
\hline $2^{\prime \prime \prime}-\mathrm{OH}$ & $18.59, \mathrm{~s}$ & - \\
\hline $\begin{array}{l}9,9^{\prime}, 9^{\prime \prime}, 9^{\prime \prime \prime}, 8-\mathrm{Me}, 8^{\prime}-\mathrm{Me}, \\
8^{\prime \prime}-\mathrm{Me}, 8^{\prime \prime \prime}-\mathrm{Me}\end{array}$ & $\begin{array}{l}\text { 1.24-1.35, } 24 \mathrm{H} \text {, } \\
\text { overlapping }\end{array}$ & $\begin{array}{l}19.0,19.2,19.4,19.5,19.5 \\
19.5,19.9,20.0\end{array}$ \\
\hline
\end{tabular}

a ${ }^{1} \mathrm{H}(500 \mathrm{MHz})$ and ${ }^{13} \mathrm{C}(125 \mathrm{MHz})$ in $\mathrm{CDCl}_{3}$.

from molecular modelling ${ }^{5}$ and the experimental NOE data was performed. A strong NOE observed between 5'-Me and 5'"'-Me, together with the absence of an NOE contact between 5-Me and $5^{\prime \prime \prime}$-Me as well as 5'-Me and 5"-Me, indicated that the benzene ring and the cyclohexadienone ring were directly linked. Taking into consideration all these data, one moiety of pilidiostigmin was fully established as fragment 1 (Fig. 2).

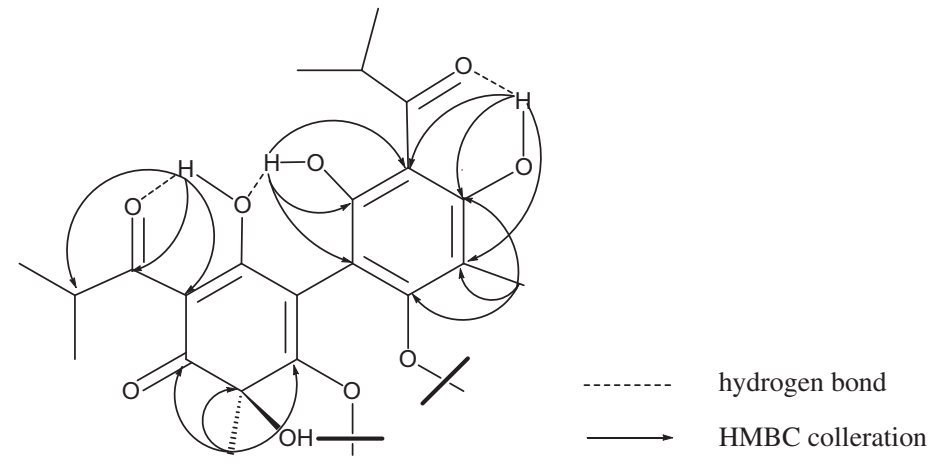

Figure 2. HMBC correlations and hydrogen bonds of fragment 1 of pilidiostigmin. 


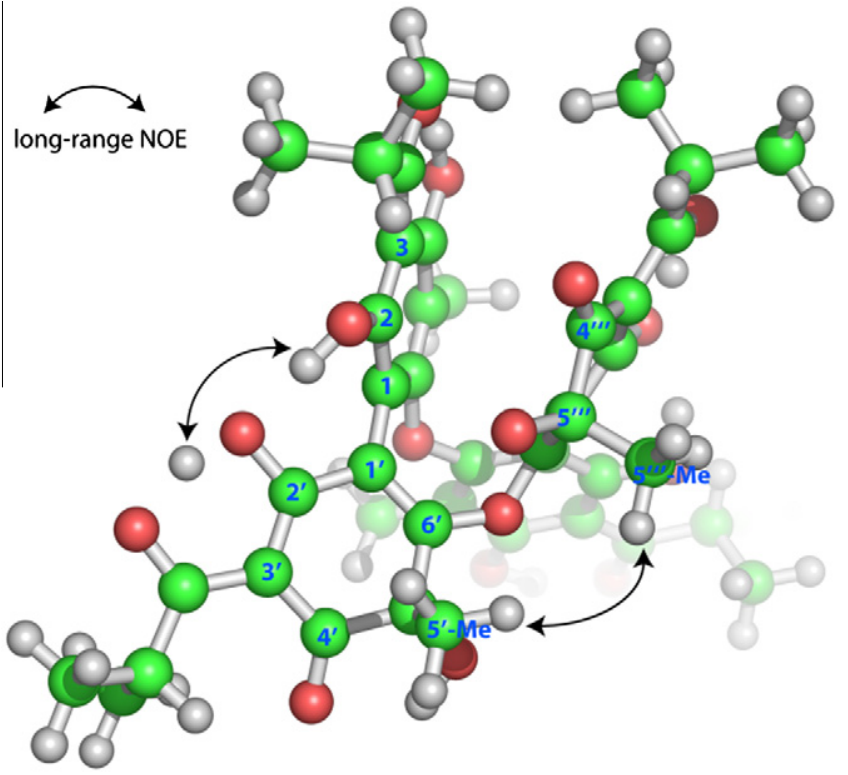

Figure 3. Selected long-range NOEs indicating the $R, R$ or $S, S\left(C-5^{\prime}, C-5^{\prime \prime \prime}\right)$ relative configuration. The optimized structure was obtained from DFT calculations at the B3LYP/6-31(d) level. The position of the sodium ion in the molecule has not been determined.

The ${ }^{13} \mathrm{C}$ NMR spectroscopic data of fragment 2 (the other part of the dimer) were closely related to those of fragment 1 . The main differences between them were the carbon signals of the two cyclohexadienone rings: $\mathrm{C}-1^{\prime}\left(\delta_{\mathrm{C}} 117.2\right), \mathrm{C}-2^{\prime}\left(\delta_{\mathrm{C}} 187.8\right), \mathrm{C}-3^{\prime}\left(\delta_{\mathrm{C}}\right.$ $105.8), \mathrm{C}-4^{\prime}\left(\delta_{\mathrm{C}} 196.6\right), \mathrm{C}-5^{\prime}\left(\delta_{\mathrm{C}} 73.4\right)$, and C-6' $\left(\delta_{\mathrm{C}} 164.4\right)$ for fragment 1 compared to C- $1^{\prime \prime \prime}\left(\delta_{\mathrm{C}} 114.3\right), \mathrm{C}-2^{\prime \prime \prime}\left(\delta_{\mathrm{C}} 182.5\right), \mathrm{C}-3^{\prime \prime \prime}\left(\delta_{\mathrm{C}}\right.$ $106.5), \mathrm{C}-4^{\prime \prime \prime}\left(\delta_{\mathrm{C}} 202.0\right), \mathrm{C}-5^{\prime \prime \prime}\left(\delta_{\mathrm{C}} 70.3\right)$, and C-6"' $\left(\delta_{\mathrm{C}} 159.8\right)$ for fragment 2 (Table 1 ). These variances indicated a different chemical environment of the carbons in the cyclohexadienone ring of fragment 2 due to a change of the electron density distribution. According to the HR-ESI-TOF-MS data, the isolated compound contained a sodium ion in the molecular formula; the presence of a sodium ion was also consistent with the asymmetric structure of the dimer. Systematic analysis of the NMR data suggested that the sodium ion was associated with a deprotonated hydroxyl group at position C-5"'; this also explained why the carbon chemical shifts of the cyclohexadienone ring in fragment 2 were different from those of fragment 1 .

The relative configuration at $\mathrm{C}-5^{\prime}$ and $\mathrm{C}-5^{\prime \prime \prime}$ was established based on a comparison of the structural models from the molecular modeling and the NOE data. Only one conformation per possible relative configuration was found in a conformational search using molecular mechanics calculations, which was further optimized with DFT (density functional theory) at the B3LYP/6-31G(d) level. The low-field chemical shift of the $2-\mathrm{OH}$ proton $\left(\delta_{\mathrm{H}} 10.58\right)$ together with the NOE contact between $2-\mathrm{OH}$ and $2^{\prime}-\mathrm{OH}$ (Fig. 3) suggested that the 2-OH proton was hydrogen bonded to the oxygen of $2^{\prime}-$ $\mathrm{OH}$, as shown in Figure 2. Taking this into account, NOE contacts between $\mathrm{H}-2-\mathrm{OH}$ and $\mathrm{H}-5^{\prime \prime \prime}-\mathrm{Me}$, as well as between $\mathrm{H}-2^{\prime}-\mathrm{OH}$ and $\mathrm{H}-5^{\prime \prime}$-Me should be observed if pilidiostigmin had the relative configuration of $R, S$ or $S, R\left(C-5^{\prime}, C-5^{\prime \prime \prime}\right)$. The absence of these two contacts together with the strong NOE contact between $\mathrm{H}-5^{\prime}$-Me and $\mathrm{H}-5^{\prime \prime \prime}$-Me (Fig. 3) were in good agreement with the suggested structural model and the relative configuration $R, R$ or $S, S\left(C-5^{\prime}, C-\right.$ $\left.5^{\prime \prime \prime}\right)$.

Pilidiostigmin is an unusual dimeric acylphloroglucinol derivative containing a sodium ion. In order to exclude the possibility of this being an artifact arising from the addition of a sodium ion during the isolation process, we tracked the compound in the crude ethanol extract using HPLC-ESIMS. A mass signal was clearly observed with a $[\mathrm{M}-1]^{-}$peak at 853 at the same retention time as pilidiostigmin (see the Supplementary data), which confirmed the natural origin of pilidiostigmin as a sodium salt. ${ }^{6}$

Pilidiostigmin was evaluated for its cytotoxicity ${ }^{7}$ and for its ability to inhibit nitric oxide (NO) production in LPS-stimulated RAW 264.7 mouse macrophage cells. ${ }^{8}$ The cytotoxicity $\left(\mathrm{EC}_{50}\right)$ of pilidiostigmin was $8.65 \mu \mathrm{M}$, and the dose-dependent inhibition of pilidiostigmin on NO production was $21.0 \%, 37.1 \%$, and $60.6 \%$ at concentrations of $0.29,0.87$, and $7.8 \mu \mathrm{M}$, respectively, indicating quite a potent inhibitory activity. Thus, pilidiostigmin, a dimeric acylphloroglucinol derivative isolated from the endemic Australian plant $P$. glabrum, and containing a sodium ion, inhibits the production of nitric oxide. Further examination of the biological activity of this unusual compound is warranted to establish its utility as a potential anti-inflammatory bioactive molecule, for example in wound healing applications and in inflammatory disorders.

\section{Acknowledgements}

This work was supported by the Wound Management Innovation CRC (established and supported under the Australian Government's Cooperative Research Centres Program). We thank Mr. Graham Macfarlane, of Chemistry \& Molecular Biosciences, University of Queensland, for determining the accurate mass, and Dr. Tanja Grkovic, Eskitis Institute for Cell and Molecular Therapies, Griffith University, for recording the CD spectrum of pilidiostigmin.

\section{Supplementary data}

Supplementary data (UV, CD, MS, and NMR spectra of pilidiostigmin) associated with this article can be found, in the online version, at http://dx.doi.org/10.1016/j.tetlet.2013.01.107.

\section{References and notes}

1. Harden, G. In Flora of New South Wales; Royal Botanic Gardens: Sydney, 2002; Vol. 2, p 231.

2. Shou, Q.; Banbury, L. K.; Renshaw, D. E.; Lambley, E. H.; Mon, H.; Macfarlane, G. A.; Griesser, H. J.; Heinrich, M. M.; Wohlmuth, H. J. Nat. Prod. 2012, 75, 16121617.

3. Onodera, J.; Obara, H.; Hirose, R.; Matsuba, S.; Sato, N.; Sato, S.; Suzuki, M. Chem. Lett. 1989, 18, 1571-1574.

4. Obara, H.; Onodera, J.; Machida, Y.; Yada, S. Bull. Chem. Soc. Jpn. 1989, 62, 30343035.

5. Molecular modelling. The initial structures of pilidiostigmin with two possible relative configurations $\left(C-5^{\prime} R, C-5^{\prime \prime \prime} R\right.$ and $\left.C-5^{\prime} R, C-5^{\prime \prime \prime} S\right)$ were generated with Discovery Studio 2.5 (Accelrys), and all trial structures were first minimized based on molecular mechanics calculations (CHARMM force field). To sample the conformational space, a conformational search was performed (BEST method in Discovery Studio 2.5) based on molecular mechanics calculations (CHARMM force field). Only one conformer for each possible configuration occurred within a $10 \mathrm{kcal} / \mathrm{mol}$ energy window from the global minimum. The orientations of the side chains of the minimized structures were adjusted so that the hydrogen bonds of the hydroxyl protons could be formed. The obtained structures were chosen for geometry optimization using DFT with the B3LYP functional and the $6-31(\mathrm{~d})$ basis set with the GAUSSIAN09 program.

6. Pilidiostigmin, a yellow oil; UV $(\mathrm{MeOH}) \lambda_{\max }(\log \varepsilon) 256.0$ (4.46), 284.0 (4.44) $\mathrm{nm} ; \mathrm{CD} \lambda_{\max }(\mathrm{MeOH}, 0.20 \mathrm{mg} / \mathrm{mL}) \Delta \varepsilon_{283}+0.17, \Delta \varepsilon_{307}-0.13 ;{ }^{1} \mathrm{H}$ NMR $(500 \mathrm{MHz}$, $\left.\mathrm{CDCl}_{3}\right)$ data, see Table $1 ;{ }^{13} \mathrm{C}$ NMR $\left(125 \mathrm{MHz}, \mathrm{CDCl}_{3}\right)$ data see Table 1 ; ESI-MS $855.3[\mathrm{M}+1]^{+}$, 853.3 $[\mathrm{M}-1]^{-}$; HRESI-MS $\mathrm{m} / \mathrm{z} 855.2622[\mathrm{M}+1]^{+}$(calcd for $\mathrm{C}_{44} \mathrm{H}_{48} \mathrm{NaO}_{16}, 855.2840$ ), $853.2707[\mathrm{M}-1]^{-}$(calcd for $\mathrm{C}_{44} \mathrm{H}_{46} \mathrm{NaO}_{16}, 853.2684$ ).

7. Cytotoxicity assay. Cytotoxicity in RAW 264.7 murine leukemic monocytemacrophages (ATCC, Manassas, VA, USA) was assayed in 96-well plates using the ATPlite ${ }^{\mathrm{TM}}$ Assay kit (PerkinElmer, Glen Waverley, Australia) with chlorambucil (Sigma C0253) as a positive control. Cells were grown in clear 96-well plates. The growth medium consisted of color-free Dulbecco's Modified Eagle's medium containing $10 \%(\mathrm{v} / \mathrm{v})$ fetal bovine serum (FBS; Interpath, Heidelberg, Australia), L-glutamine $(2 \mathrm{mM})$, sodium pyruvate $(1 \mathrm{mM})$, penicillin $(200 \mathrm{U} / \mathrm{mL})$, and streptomycin $(200 \mu \mathrm{g} / \mathrm{mL})$ (all from Invitrogen, Mulgrave, Australia). Cells were plated out at a concentration of 30,000 cells/ well $(90 \mu \mathrm{L}$ cell suspension/well), test and control compounds dissolved in DMSO at six concentrations and further diluted 20-fold in media were added to 
the cell suspension at $10 \mu \mathrm{L} /$ well, and the plates were incubated at $37^{\circ} \mathrm{C}$ with $5 \%$ $\mathrm{CO}_{2}$ for $24 \mathrm{~h}$. Following incubation, cell lysates were assayed for ATP with the ATPlite $^{\mathrm{TM}}$ assay kit as per the manufacturer's instructions. Briefly, all kit components were equilibrated to room temperature. Mammalian cell lysis solution $(50 \mu \mathrm{L})$ was added to each well of the cell culture microplate, the plate was shaken on an orbital microplate shaker ( $500 \mathrm{rpm}, 5 \mathrm{~min}$ ), then substrate solution $(50 \mu \mathrm{L} /$ well) was added and the plate was further shaken $(500 \mathrm{rpm}$, $5 \mathrm{~min}$ ). The plate was dark adapted for $10 \mathrm{~min}$ and the luminescence was measured on a Wallac 1450 Microbeta luminescence counter (Wallac, Turku, Finland). Half-maximal inhibitory concentration $\left(\mathrm{IC}_{50}\right)$ values were calculated using GraphPad Prism version 4 (La Jolla, CA, USA). Samples were assayed in triplicate.
8. Nitrite (Griess) assay. RAW 264.7 cells were cultivated as described above. Cell suspension $\left(120 \mu \mathrm{L} /\right.$ well, $0.6 \times 10^{6}$ cells $\left./ \mathrm{mL}\right)$ was added to the wells of a 96-wel microplate and incubated for $20 \mathrm{~h}\left(37^{\circ} \mathrm{C}, 5 \% \mathrm{CO}_{2}\right)$, after which test compounds dissolved in DMSO were added. Following incubation for $1 \mathrm{~h}$, LPS solution $(10 \mu \mathrm{L} /$ well, $10 \mu \mathrm{g} / \mathrm{mL})$ was added and the plate was incubated for a further $20 \mathrm{~h}$. NO produced was determined spectrophotometrically by assaying nitrite in the cell supernatants using the Griess reagent. Absorbance was measured at $550 \mathrm{~nm}$ in a Wallac Victor 2 plate reader (Wallac, Turku, Finland) and the nitrite concentration was determined by reference to a sodium nitrite standard curve. Samples and controls were assayed in triplicate. 